\title{
Family involvement and Spanish hotel chains' entry modes abroad
}

\author{
Rosario Andreu ${ }^{\mathrm{a} *}$, Enrique Claver-Cortés ${ }^{\mathrm{a}}$, Diego $_{\text {Quer }}{ }^{\mathrm{a}}$ and Laura Rienda ${ }^{\mathrm{a}}$
}

${ }^{a}$ Business Management Department

University of Alicante

Faculty of Economics and Business

Carretera San Vicente del Raspeig s/n

03690 San Vicente del Raspeig - Alicante (Spain)

Tel. (+34) 965903606

*Contact: Rosario Andreu rosario.andreu@ua.es

\begin{abstract}
The aim of this study is to analyze the relationship between family involvement and entry mode choice by Spanish hotel chains in foreign markets. Drawing on stewardship and institutional theories, we examine how family character may moderate the effect of institutional differences on the choice of entry modes entailing different levels of resource commitment and control over international activities. Using a sample of 981 hotels established abroad by 76 Spanish hotel chains, the results show that family involvement is associated with entry modes involving greater control and resource commitment. Moreover, family involvement moderates the relationship between both formal and informal institutional distance and entry mode choice. Specifically, when both distances are high, family involvement increases the likelihood of choosing entry modes involving higher control and resource commitment.
\end{abstract}


Keywords: Hotel chains; family firms; foreign market entry mode; formal institutional distance; cultural distance.

\section{Introduction}

Even though family businesses (FBs) have traditionally grown within domestic markets, many of them have been compelled to go abroad in order to survive in highly competitive and globalized markets (Kontinen \& Ojala, 2010). Hence, FBs' internationalization has become one of the most outstanding phenomena in the last few decades (Arregle, Duran, Hitt \& van Essen, 2017). However, prior studies failed to obtain conclusive results on whether these firms have a higher propensity to internationalize than non-family businesses (NFBs) due to the wide range of theories from which this topic has been addressed.

Building upon the socio-emotional wealth (SEW) perspective, Gómez-Mejía, Makri and Larraza (2010) found that FBs showed a lower level of internationalization than NFBs due to their desire to keep control in the family's hands. Other obstacles for the international expansion of FBs are lack of capital and resources, absence of a professionalized management, reluctance to change, family conflicts, and risk aversion (Arregle et al., 2017; Fernández \& Nieto, 2005; Sciascia, Mazzola, Astrachan \& Pieper, 2012).

Nevertheless, there is an opposite view that stresses the positive attributes of these firms leading them to a greater level of internationalization. The executives' strong identification with the motivations of the firm, flexibility, faster decision-making, and longterm orientation can encourage managers to carry out riskier strategies such as internationalization (Zahra, 2003). Theories related to the behavior of managers strongly identified with the firm (such as the stewardship theory) help to reinforce the arguments underpinning this point of view that suggests a higher level of internationalization by FBs. As 
pointed out by Eddleston and Kellermanns (2007), the stewardship theory is a suitable perspective in viewing the family as a resource instead of a limitation.

Other possible explanations for this lack of consensus on the link between FBs and internationalization are the variety of measures used to conceptualize family character (Boyle, Pollack \& Rutherford, 2012) and the influence exerted by other variables such as industry and institutional factors (Arregle et al., 2017). For that reason, Kontinen and Ojala (2010) suggest the need to carry out further studies about FBs focusing on specific industries, in particular service industries, since past research mainly focused on manufacturing sectors. Furthermore, most prior studies on FBs analyzed small- and medium-sized enterprises (SMEs), paying less attention to larger firms. Therefore, our study fulfills this twofold requirement, since it refers to a single service sector -the Spanish hotel sector- and does not exclusively focus on SMEs, since it includes all the internationalized FBs that operate in this industry.

The Spanish hotel industry has a high percentage of FBs (Andreu, Claver, Quer \& Rienda, 2018). Besides, in recent decades, this sector has experienced an explosive growth and has reached a high level of internationalization (Andreu, Claver \& Quer, 2017a; Brida, Driha, Ramón \& Scuderi, 2015). However, to our knowledge, no studies have discussed the extent to which the family character influences the international strategies of Spanish hotel firms. Thus, this study aims to provide new evidence about the relationship between family character and international decisions by Spanish hotel chains, in particular, those related to entry mode choice in foreign markets. More precisely, drawing on the stewardship and institutional theories, our aim is to investigate whether the family character of Spanish hotel firms moderates the relationship between institutional differences and the choice of entry modes involving higher levels of control and resource commitment.

Our study develops several contributions. First, it complements the literature on FB internationalization from the stewardship perspective within a service sector that has received 
less attention. Moreover, we provide new evidence about the role played by family character when it comes to institutional factors and entry mode choice -an under-researched topic in the FB literature. Our study additionally provides new empirical evidence about entry strategies in the hotel industry, which has certain peculiarities (Chen \& Dimou, 2005; Dimou, Chen \& Archer, 2003; Kruesi, Hemmington \& Kim, 2018) and is under-explored compared to manufacturing industries (Brouthers \& Brouthers, 2003; Kruesi, Kim \& Hemmington, 2017; Pla \& Ghauri, 2012).

The paper is structured as follows. The next section examines entry mode decisions by FBs in the hotel industry. Based on the stewardship and institutional theories, we propose several hypotheses regarding how family character influences entry mode choice. Then, we describe our empirical research and report the main findings. After the discussion of our results, we highlight the contributions and limitations of our paper and suggest future research lines on this topic.

\section{Theory and hypotheses}

\section{Entry modes by FBs in the hotel industry}

Even though the stewardship theory has been available for some decades, its application to FBs is quite recent (Miller, Le Breton-Miller \& Scholnick, 2008). One of its basic principles is that managers' interests can be aligned with those of the owners (Lee \& O'Neill, 2003). This theory was proposed by Davis, Schoorman \& Donaldson (1997) as an alternative perspective to the limitations of agency theory. Agency theory is built on the assumption of interest divergence (agency problem) between shareholders (principals) and top managers that can behave as agents and seek maximize their own utility (Donaldson \& Davis, 1991). This agency relationship is associated with the separation of ownership and control. In FBs, if both ownership and management were under the control of the family, this duality of interests 
would be less probable-or even could not exist. In these firms, it is more likely that there is an identification of managers with the organization. Managers are not motivated by individual goals, but rather are stewards whose motives are aligned with the objectives of their principals (Davis et al., 1997).

The business is considered as a way to support the family in the future, giving continuity and security to the next generations (Miller et al., 2008). For that reason, these firms invest in creating conditions to ensure long-term profits for all family members (Gómez-Mejía, Haynes, Nunez-Nickel, Jacobson \& Moyano-Fuentes, 2007). In their efforts to guarantee continuity and survival, FBs will most probably undertake fast growth strategies, which may lead them to gain a larger market share or even to expand toward new markets. Thus, Zahra (2003) proposes that higher family involvement has a positive effect on the decision to enter international markets. This suggests that FBs accept the risk associated with internationalization, or they perceive lower risk-i.e. they are less risk-averse.

Entry mode choice is a key decision of the internationalization process. The options available for hotel firms to establish in other countries may be grouped together around two large categories, depending on whether foreign direct investment (FDI) is carried out or not. Firms choose ways that involve an FDI when they want to maximize control and are in a position to assume greater resource commitment and a higher risk level. Otherwise, firms will opt for contractual agreements. Within the former category, referred to as 'asset-light' modes, management contracts and franchising are the most common in the hotel industry (Dimou et al., 2003; Kruesi et al., 2017). In management contracts, hotel chain selects the hotel manager, implements their policies, their systems and procedures and is responsible for all hotel operations. The hotel is managed as if it was owned by the chain (Pla, León \& Villar, 2011). In franchise agreements, the chain does not manage the hotel. It gives their brand name to the 
owner of the hotel whose controls the daily operations and physical assets (León, Villar \& Pla, 2011).

Anyway, it is worth mentioning that hotel chains also use lease agreements or leasing. In leasing, the hotel chain rents a building and runs the entire operation independently. It may be considered as a contractual entry mode, even though in practice it would lie closer to ownership-based modes. In the context of this study, lease agreements can be treated in the same way as equity modes. They are an 'asset-heavy', risky and costly way to develop operations. With lease agreements, the balance sheet would become too heavy by having continual lease payments as fixed expenses (Kruesi et al., 2018).

When it comes to entry mode choice, ownership is equivalent to control and, therefore, increasing ownership means increasing control (Agarwal \& Ramaswami, 1992). However, the separation between management and ownership ('bricks and brains' split) of the non-equity entry modes used in the international hotel industry makes it possible to retain control over operations regardless of the capital investments. Contractor and Kundu (1998) classify entry modes in the hotel sector based on the degree of control over daily management and service quality, physical assets, tacit expertise, and codified strategic assets. Fully owned hotels are the entry mode that provides a higher control over all the criteria. On the opposite side would be franchising that only provide strong control over strategic assets while having lower level of resource commitment. A management contract provides more strategic and operational control than franchising, but is more resource intensive (Kruesi at al., 2017).

From the stewardship perspective, family members involved in managing and operating the business could promote the firm's propensity toward risk taking. As Vargas (2001) points out, one of the differences with regard to the agency theory is that stewardship theory defends that the principal or owner has more risk propensity. The stronger identification with the values of the firm and the family may lead FBs to prioritize such 
feelings when they adopt strategic decisions such as internationalization. FBs may prefer to keep control over international activities because of their stronger commitment to the firm, along with their desire of protection. Therefore, these companies may choose entry modes that involve higher resource commitment, despite the higher risk. The desire to control the firm will grow when FBs have several family members actively involved in the firm's management and ownership (Miller et al., 2008). Accordingly, we propose the following hypothesis:

Hypothesis 1: Family firm involvement is positively associated with the choice of entry modes involving higher control and resource commitment.

\section{Institutional environment, family firm character and entry mode by hotel chains}

Some of the most influential factors on entry mode decisions are the political, social and economic systems that shape the institutional environment-both of the host and the home countries. This institutional context establishes the rules of the game in a society and determines the behavior of social players (North, 1990). The institutional theory helps to explain how formal institutions (such as political rules, legal decisions and economic measures) and informal ones (behavioral patterns, identity, customs and traditions embedded in culture and ideology) influence firm's behavior (Peng, 2000).

As for the analysis on how the institutional context determines the entry mode, we can separately consider the influence of formal and informal institutions, because differences are likely to exist. Therefore, two different but related lines of research have examined the impact of these two institutional components in the strategic decision-making of the company, including internationalization strategy and entry mode (Arregle et al., 2017; Slangen \& van Tulder, 2009). 
Formal and informal institutional differences between host and home countries increase the external uncertainty associated with establishing in a foreign destination. This situation is perceived as riskier and will most probably influence the entry strategy (Chen, Cui, Li \& Rolfe, 2017). In relation to formal institutions, the risk level perceived will depend on the differences and similarities between the standards and rules of the game established in the destination country and those prevailing in the country of origin. The greater the formal institutional difference, the harder it will be for the firm to establish in that country due to factors such as higher economic risk, greater political uncertainty, existence of asymmetric information, higher administrative and organizational costs, and riskier relationships with local institutions (Pinto, Ferreira, Falaster, Fleury \& Fleury, 2017). Consequently, the firm will have greater difficulties and costs to establish and do business in that country. This can lead it to use entry modes that entail smaller resource investment, but also less control over the international activity. In this case, a negative relationship between formal institutional differences and the entry by means of modes implying higher control and resource commitment could be expected (Brouthers 2002; Pak \& Park, 2004).

In turn, informal institutional distance is mainly related to differences in terms of culture between host and home countries (Schwens, Eiche \& Kabst, 2011). Cultural distance stands out as one of the variables most commonly utilized to measure external uncertainty (Zhao, Luo \& Suh, 2004). Cultural distance refers to the possible differences existing between the way in which individuals from different countries observe certain behaviors, which will affect the validity of the transfer of working practices and methods from one country to another (Hofstede, 1980). Greater cultural differences between countries increase the costs and risks associated with doing business in the host country. Despite the lack of consensus on the sign of the relationship between cultural distance and entry modes, numerous studies have 
proved that a negative relationship exists with modes involving higher resource investment (Brown, Dev \& Zhou, 2003; Gatignon \& Anderson, 1988; Pak \& Park, 2004).

Anyway, the behavior shown by FBs when choosing an entry mode may differ from that of NFBs (Kraus, Mensching, Calabrò, Cheng and Filser, 2016). This makes necessary to complement the insights derived from the institutional theory, since very few studies have dealt with the effects of institutions on the entry strategies by FBs (Wright, Chrisman, Chua \& Steier, 2014).

As we stated above, the family's involvement in the business may reduce ownermanagers' perceptions of the risks associated with complex investment decisions during the internationalization process (James, 1999). As a consequence, FBs could choose entry modes that imply higher resource commitment and ensure more control over foreign activities, despite the higher risks that they entail when there are institutional differences between countries (Kraus et al., 2016).

As a result, the negative relationship between formal and informal institutional differences and the choice of entry modes that entail higher resource commitment and control may be moderated by family involvement. This leads us to propose the following hypotheses:

Hypothesis 2: Family firm character moderates the negative relationship between formal institutional differences and the choice of entry modes involving higher control and resource commitment, in such a way that the impact will decrease as family involvement grows.

Hypothesis 3: Family firm character moderates the negative relationship between informal institutional differences and the choice of entry modes involving higher control and resource commitment, in such a way that the impact will decrease as family involvement grows. 
Figure 1 depicts the conceptual model we propose.

Insert Figure 1 about here

\section{Methodology and data}

\section{Data collection}

The Spanish hotel chains listed in the 2016 Alimarket Hotel and Catering Yearbook were selected to test our hypotheses. This database brings together financial and commercial data of the most important hotel chains with headquarters based in Spain (including both national chains and international groups establish in this country). To build the database, we removed duplicated observations, data on companies and funds only owning hotel properties, firms specialized in the operation of establishments with third-party trademarks, as well as independent hotel groups-also known as voluntary chains.

The original database included 697 hotel chains. Our study only analyzed international chains, namely, those having hotels outside Spain whether they are on a franchise, management, lease agreements or ownership basis. Finally, we identified 76 international Spanish hotel chains with 981 hotels abroad, this being the sample of our study. Table 1 reports a description of the sample.

Insert Table 1 about here

\section{Dependent variable}

Entry mode. Based on previous studies (Berbel \& Ramírez, 2011; Contractor \& Kundu, 1998; García de Soto \& Vargas, 2015; Ivanova \& Ivanov, 2014; Ramón, 2002), we defined a variable coded with four categories: (1) when the firm operates the hotel abroad under a franchise agreement; (2) when the firm operates it under a management agreement; (3) if the hotel is operated on a lease contract; and (4) if the firm has the partial or total ownership and 
management of the foreign establishment ${ }^{1}$. This variable represents an ordinal scale of the degree of control and resource commitment. While both franchising and management agreements are contractual forms, management agreements offer more operational and strategic control, thus being closer to a quasi-internalized transaction (Contractor \& Kundu, 1998; Pla, Sánchez \& Madhok, 2010). Besides, despite not entailing large investments, management contracts involve a certain level of resource commitment. This is because the need to transfer assets-such as knowledge for local management training or the expatriation of staff from one country to another-, as well as the pre-opening costs and the need to obtain local information (Dimou et al., 2003). In turn, a franchising agreement not only means lesser resource commitment but also a lower level of control, thus being a quasi-market transaction (Kruesi et al., 2017). Lease contracts (which can almost be considered as an equity-based entry mode), and the ownership of hotels abroad are entry modes which, in addition to involving higher resource commitment, allow the firm to exert more control (Dimou et al., 2003; Kruesi et al., 2017, 2018).

\section{Explanatory variables}

Formal institutional distance. To operationalize formal institutional differences, we based on the six dimensions of the Worldwide Governance Indicators (WGI) of the World Bank for measuring the governance infrastructure quality of a country (Kaufmann, Kraay \& Mastruzzi, 2009): voice and accountability, political stability and absence of violence, government effectiveness, regulatory quality, rule of law, and control of corruption. Drawing on these dimensions, we calculated the formal institutional distance between Spain and each host country using the same methodology developed by the Kogut and Singh's (1988) index for measuring cultural distance between countries (Malhotra \& Gaur, 2014; Slangen, 2011). Thus, we measured formal institutional distance as follows:

\footnotetext{
${ }^{1}$ Lack of data prevented us from distinguishing between partially-owned (joint-venture) and wholly-owned hotels.
} 


$$
\mathrm{ID} j=\sum_{\mathrm{i}=1}^{6}\left\{(\mathrm{I} i j-\mathrm{I} i s p)^{2} / \mathrm{V} i\right\} / 6
$$

Where $\mathrm{ID}_{j}$ is the formal institutional distance between country $j$ and Spain, $\mathrm{I}_{i j}$ is country $j$ 's score on the $i_{t h}$ institutional dimension, $\mathrm{I}_{i s p}$ is the score of Spain on this dimension, and $\mathrm{V}_{i}$ is the variance of the score of the dimension.

Cultural distance. This variable was used as a proxy of informal institutional differences. We measured the cultural distance between Spain and each host country using the Kogut and Singh (1988) index, based on the extended Hofstede's model with six dimensions (Hofstede, Hofstede \& Minkov, 2010). These dimensions are power distance, uncertainty avoidance, individualism versus collectivism, masculinity versus femininity, long-term versus short-term orientation, and indulgence versus restraint. We calculated cultural distance as follows:

$$
\mathrm{CD} j=\sum_{\mathrm{i}=1}^{6}\left\{(\mathrm{I} i j-\mathrm{I} i s p)^{2} / \mathrm{V} i\right\} / 6
$$

Where $\mathrm{CD}_{j}$ is the cultural distance between country $j$ and Spain, $\mathrm{I}_{i j}$ is country $j$ 's score on the $i_{t h}$ cultural dimension, $\mathrm{I}_{i s p}$ is the score of Spain on this dimension, and $\mathrm{V}_{i}$ is the variance of the score of the dimension.

\section{Moderating variable}

Family involvement. Despite the lack of consensus on how to conceptualize a FB, the two most frequently used criteria have been the levels of ownership and management in the family's hands (Abdellatif, Amann \& Jaussaud, 2010; Kraus et al., 2016). A FB can be defined considering family ownership, management or both (Arregle et al., 2017). We used the percentage of the firm's equity held by the owner family and the percentage of family members in board management positions (Zahra, 2003) in order to classify firms into several categories. Based on Arregle et al. (2017), we established five mutually exclusive categories: 
(1) Firms with less than 10 per cent of the firm's capital in the hands of the family and less than two family managers (this being NFBs) ${ }^{2}$; (2) Firms with more than 10 per cent of the firm's capital in hands of the family and more than two managers in management positions but whose percentage is still minority in both ownership and management (firms with low family involvement); (3) Firms with a majority presence of family members in management positions but not in ownership (family-managed firms); (4) Firms with a majority percentage of family presence in ownership but not in management positions (family-owned firms); (5) Firms with a majority family presence in both ownership and management positions (familyowned and family-managed firms). This variable represents an ordinal scale of family involvement and control. Family members with a substantial ownership and top management presence allow FBs to exert significant influence on firm's strategic decisions and operations. This provides the family with the opportunity to seek specific family goals (Arregle et al., 2017).

\section{Control variables}

We also included a number of control variables that, according to prior research, might also influence entry mode choice.

International experience. International experience is a determinant factor when choosing entry modes (Gatignon \& Anderson, 1988). International experience allows the company to better adapt to the particular host market (Niñerola, Campa, Hernández \& Sánchez, 2016). Companies without international experience are likely to have more difficulties in managing foreign operations, thus preferring entry modes demanding lower resource commitment (Agarwal \& Ramaswami, 1992). We measured international experience using two variables: the number of years since a firm's internationalization process began (Brida, Ramón, Such \& Driha, 2016; Driha \& Ramón, 2011; García de Soto \& Vargas, 2015;

\footnotetext{
${ }^{2}$ According to Gómez-Mejía et al. (2010), a firm is considered a FB if both of the following conditions are met: two or more managers must have a family relationship and family members must hold at least a 10 per cent of the firm's capital stock.
} 
León et al. 2011; Martorell, Mulet \& Pla, 2013; Pla et al., 2010; 2011; Ramón, 2002); and the ratio of rooms abroad to total rooms of each hotel chain (Brida et al., 2016; Lu \& Beamish, 2004; Ramón, 2002; Tallman \& Li, 1996).

Firm size. Firms may adopt different patterns of internationalization based on their financial and managerial resource limitations (Brida et al., 2015). Several studies found a positive relationship between firm size and equity-based entry modes, since large companies have more resources to carry out FDI (Brouthers, 2002; Driha \& Ramón, 2011; Pla et al., 2010). Nevertheless, other researchers reported a negative relationship, since larger firms may need to find partners in order to enter specific locations (Brown et al., 2003; Contractor \& Kundu, 1998; Martorell et al., 2013) or because larger firms possess the capabilities and knowledge needed to choose a contractual agreement (León et al., 2011). Hence, we controlled for firm size using the average income of each hotel chain in the last three years, with a logarithmic transformation to normalize the variable distribution (Brida et al., 2016; García de Soto \& Vargas, 2015; Ramón, 2002).

Family generation. Control, influence and emotional attachment have a stronger weight in first generations of a FB (Berrone, Cruz \& Gómez-Mejía, 2012). Founders try to perpetuate their legacy and ensure continued family control (Miller, Steier \& LeBreton-Miller, 2003). Therefore, they may be willing to undertake riskier strategies. Accordingly, Claver, Rienda \& Quer (2007) found that first generations perceive less risk when doing business abroad. To the extent that risk aversion increases with successive generations, the use of nonequity entry modes could be negatively related to the FB's generation. Future generations are considered as stewards of their inheritance and have a duty to preserve the family position. Entering new markets can induce major organizational changes, and this is likely to generate resistance from family members as they feel that their degree of control is being threatened (Gómez-Mejía et al. 2010). However, Graves and Thomas (2008) argued that successors 
came with a fresh understanding of the importance of internationalization. Thus, international involvement may be encouraged by the presence of the second and subsequent generations (Fernández \& Nieto, 2005). In line with this reasoning, Claver, Rienda and Quer (2008) found a positive relationship between the generation and the choice of entry modes involving higher international commitment. Consequently, we controlled for the current generation of the family that is running the firm, using a continuous variable.

Family CEO. The presence of a family CEO can facilitate the alignment of interests between ownership and management. Besides, a family CEO may provide a better internal control mechanism and better access to resources (Peng \& Jiang, 2010). Therefore, if the family CEO shows a long-term orientation for firm's survival, the level of internationalization would be positively influenced (Zahra, 2005) since growing across borders helps to strengthen the business in the long-run (Pukall \& Calabró, 2014). This may favored the use of entry modes that allow keeping control in the family hands. Nevertheless, some family CEOs may be unqualified (Peng \& Jiang, 2010). This lack of professionalization could affect strategic decisions on international commitment, thus diminishing the positive influence of having a family CEO. Accordingly, based on the studies of Gómez-Mejía et al. (2010) and Peng \& Jiang (2010), we included a dummy variable with value (1) for those firms where the CEO is a family member, and value (0) otherwise.

Market attractiveness. Past studies in the hotel industry reported a positive relationship between host market attractiveness and equity-based entry modes (Driha \& Ramón, 2011; Martorell et al., 2013; Ramón, 2002). Hence, we also controlled for this factor. Drawing on the World Tourism Organization (UNWTO, 2017), we used data on income obtained from tourism in each host country with a logarithmic transformation (Andreu, Claver \& Quer, 2017b; León et al., 2011; Pla et al. 2011). 
Table 2 summarizes the measurement, coding and sources of information used for each variable.

\section{Insert Table 2 about here}

\section{Results}

Data were analyzed using SPSS version 24. Table 3 shows descriptive statistics and the bivariate correlation matrix.

\section{Insert Table 3 about here}

We calculated the variance inflation factor (VIF) for all the variables as a multicollinearity test. This test measures the extent to which the variances of the coefficients estimated in a regression are inflated when compared to the cases in which the independent variables are not linearly related. High VIF values can become indicators of the existence of multicollinearity. As can be seen, the highest VIF was 4.43, which is below 10, the cut-off point recommended by Kutner, Nachtsheim, Neter \& Li (2005). This allows us to rule out the presence of multicollinearity in our data.

We used an ordinal logistic regression model for hypothesis testing. This regression model has been used in past studies on entry mode choice by hotel companies (Contractor \& Kundu, 1998; Pla et al., 2011; Ramón, 2002). A significant positive coefficient indicates that the independent variable increases the probability of choosing entry modes involving higher control and resource commitment. As Table 4 shows, we used different models for hypothesis testing. Model 1 includes only control variables. Model 2 adds the main effects of the explanatory variables and the moderator. Models 3, 4 and 5 examine the moderating influence of family involvement, thus including interactions with formal institutional distance (Model 3), with cultural distance (Model 4) and with both explanatory variables (Model 5). 
The results of Model 2 show that family involvement is positively associated with a preference for choosing entry modes that entail a high control and resource commitment $(\beta=$ $0.672, \mathrm{p}<0.05)$. Therefore, Hypothesis 1 is supported. Moreover, the direct effect of formal institutional distance is negative and highly significant in Model $3(\beta=-7.472, \mathrm{p}<0.01)$. The interaction term between formal institutional distance and family involvement is positive and statistically significant both in Model $3(\beta=1.728, \mathrm{p}<0.01)$ and Model $5(\beta=1.796, \mathrm{p}<0.01)$. These findings suggest a positive moderating effect of family involvement, namely, that it increases the likelihood of choosing entry modes with high resource commitment despite formal institutional differences between countries. Thus, Hypothesis 2 is supported.

Model 4 shows a negative and statistically significant effect of cultural distance on the choice of entry modes involving a higher control level $(\beta=-1.037, \mathrm{p}<0.01)$. The interaction term between cultural distance and family involvement is positive and statistically significant in Model $4(\beta=0.269, p<0.01)$, suggesting that family involvement moderates the relationship between cultural distance and high-control entry modes. However, the lack of significance of that interaction term in Model 5 leads us to consider Hypothesis 3 only partially supported.

In order to facilitate the interpretation of our findings, we plotted the interaction effects. As shown in Figures 2 and 3, the effect of both formal institutional distance and cultural distance is negative at low levels of family involvement and turns positive at high levels of family involvement. This result indicates that when both distances are high, family involvement increases the likelihood of choosing entry modes involving a high level of control and resource commitment. This provides further support to Hypothesis 2 and 3.

Insert Figure 2 about here

Insert Figure 3 about here 
In short, our findings suggest that Spanish hotel chains with high family involvement behave in the same way in both cases: when formal and informal institutional distances are high, they always seek high control entry modes-the straight line is positive and with a similar slope in both Figures. Conversely, those hotel chains with a low family involvement prefer entry modes implying lower levels of control and investment when there is a high formal and informal institutional distance.

As for control variables, all of them turn out to be statistically significant in all Models. Firm experience shows a positive sign, thus suggesting that Spanish hotel chains with more international experience tend to choose riskier entry modes. Firm size shows a negative sign, indicating that larger hotel chains prefer a lower resource commitment when choosing entry modes. Regarding family generation, the negative association with high control and resource commitment suggest a lower risk aversion of the founders compared to the second and subsequent generations. Moreover, the presence of a family CEO is positively associated with riskier entry strategies. Finally, host market attractiveness has a positive association with the decision to invest more resources abroad.

\section{Robustness tests}

Finally, we conducted several robustness tests in order to confirm that our findings are not due to an idiosyncrasy of the empirical model and/or estimation strategy (Meyer, van Witteloostuijn \& Beugelsdijk, 2017). The results of robustness tests are reported in Table 5.

\section{Insert Table 5 about here}

First, in Models 2a, 3a and 4a we performed the hypothesis test using the percentage of family members in management positions as an alternative measure of the moderating variable (Miller, Le Breton-Miller \& Lester, 2010; Sciascia et al., 2012; Zahra, 2003). Second, in Models 2b, $3 b$ and $4 b$ we repeated the test considering only the subsample of FBs, i.e., 
excluding NFBs-firms with less than a 10 per cent of the firm's capital stock in hands of the family and less than two managers with a family relationship (Gómez-Mejía et al., 2010).

Finally, in Models 2c, 3c and 4c we included some additional firm- and host countryspecific control variables that may also affect entry mode choice of hotel companies (Andreu et al., 2017b; Brown \& Dev, 2000; Contractor \& Kundu, 1998; Chen \& Dimou, 2005; García de Soto \& Vargas, 2015; León et al, 2011; Martorell et al., 2013; Pla et al. 2011). These variables are the number of stars of each hotel (as a proxy of resource intangibility), the number of countries where the hotel chain has foreign establishments (as a proxy of firm's geographic scope), the number of employees (as an alternative measure of firm size), and political risk (as a measure of institutional instability in the host country) ${ }^{3}$. Some of these variables were not included in our main analysis because they were correlated with other variables. The results of these robustness tests are similar to those reported in Table 4.

\section{Discussion}

Drawing on stewardship and institutional theories, our aim has been to analyze how the family character of Spanish hotel chains affects entry mode choice, in particular, whether it moderates the influence of the institutional environment on that decision.

Our results suggest that family involvement is positively related to entry modes that entail more control and resource commitment. From the stewardship perspective, we argue that FBs' managers are stewards motivated by organizational goals due to the socio-emotional link between owners and managers. Consequently, the business is considered as a way to support the family in the future, giving continuity and security to next generations. This desire

\footnotetext{
${ }^{3}$ Regarding intangible resources, it could be expected that the larger the number of intangible assets in a hotel, the greater the control that a hotel chain needs to exert in order to meet quality standards. Intangible assets grow as the number of stars increases (Brown \& Dev, 2000). As for geographic scope, prior studies used it as a proxy of international experience, suggesting that it could also affect entry mode choice (Lu \& Beamish, 2004; Tallman \& Li, 1996). More precisely, a greater geographic scope, namely, a higher international experience, will increase the likelihood of choosing equity-based entry modes (Agarwal \& Ramaswami, 1992; Contractor \& Kundu, 1998).
} 
of preserve the organization reduce owner-managers' perceptions of the risks associated with investment decisions when entering foreign countries. Thus, Spanish hotel chains that are FBs prefer entry modes that allow them to keep control over international activities.

Our findings also support the moderating effect of family involvement. Family involvement moderates the negative relationship between formal institutional distance and the level of control and investment of the entry mode chosen, proposed by the institutional theory. When family involvement is high, the relationship between formal institutional distance and equity entry modes becomes positive. In other words, Spanish family hotel chains tend to prefer high-control entry modes when there is a high formal institutional distance, thus being risk-willing instead of risk-averse.

Moreover, our findings show that family involvement moderates the relationship between cultural distance and entry mode choice. Hence, as the cultural distance increases, Spanish hotel chains with a higher family involvement prefer to use entry modes involving a higher control and resource commitment. Consequently, we can point out that, in destinations with greater informal institutional differences, Spanish family hotel chains also show a more risk-willing behavior, choosing entry modes that allow them to retain more control over international operations. However, our findings regarding the interplay between family involvement and cultural distance are less conclusive in comparison with those of the interplay between family involvement and formal institutional distance.

As stated above, many prior studies reported a negative association between cultural distance and the choice of high control and commitment entry modes. However, cultural distance not only increases the difficulty to find an appropriate local partner, but also generates additional costs when transferring know-how because of the differences in norms and routines (Contractor \& Kundu, 1998; Gaur \& Lu, 2007). Furthermore, Chen and Hu (2002) suggest that the little familiarity with target country's culture and local managers gives 
investors incentives to internalize so that subsidiaries can be more efficiently controlled. As Villar, Pla and León (2012) argued, internalization through subsidiaries will prevent hotel firms from opportunistic behavior by partners and ensure that the operation develops in accordance with the standards demanded by the hotel chain. This provides a protection against the local partner's inability to execute correctly the routines and procedures required. Therefore, the relationship between cultural distance and equity-based entry modes could also be positive, as we obtained in Model 2.

\section{Conclusions}

To our knowledge, no studies dealt with the internationalization of FBs in the Spanish hotel industry, even though this sector is characterized by a high presence of such firms. In doing so, we applied insights from the institutional theory to the context of FBs, combining them with the stewardship theory perspective, which suggest that FBs are less risk-averse. Our findings report a positive association between family involvement and more risky entry modes. Besides, family involvement moderates the relationship between formal and informal institutional differences and entry mode choice by Spanish hotel chains.

\section{Contributions and implications}

Our study provides theoretical arguments and empirical evidence to support the notion that FBs differ from NFBs in their internationalization strategies, more precisely, when choosing entry modes. From a theoretical point of view, we argued that stewardship theory is applicable when analyzing international strategies of Spanish family hotel chains. In addition, we have integrated stewardship and institutional theories in order to investigate whether family involvement influences entry mode decisions in institutionally distant host countries. Since cross-country institutional differences have been overlooked in prior empirical research on FBs (Arregle et al., 2017), our study provides new evidence on the relationship between 
formal and informal institutional differences and family involvement. Furthermore, the link between FBs and entry modes abroad has received less attention in the FB literature (Claver et al., 2007). Thus, we contribute with new empirical evidence on this topic. Our study also provides new insights on entry mode choice by hotel chains, whose peculiarities have been under-researched in comparison with manufacturing firms (Kruesi et al., 2018; Pla \& Ghauri, 2012).

Regarding managerial and policy implications, our study can encourage FB managers to place the emphasis on the different local institutional contexts, insofar as the institutional environment is becoming a key determinant of entry mode choice. It can also help home country's administrations to take an interest in adapting the regulations or making it easier for FBs to enter those destinations with which the home country has fewer institutional similarities. Actually, government policy shapes the environment in which firms operate by setting the rules of the game through policy formation and regulations that affect firm behavior (Nguyen, Kim \& Papanastassiou, 2018). Thus, entry modes implying lesser resource commitment, such as franchising, could be used to a greater extent by FBs, provided that the necessary conditions exist to ensure a suitable relationship with foreign partners.

\section{Limitations and future research}

We would also point out the limitations of our study that open avenues for future research. First, we based our empirical analysis on secondary data sources. For this reason, we were unable to capture the managers' perceptions on how institutional differences matter when choosing entry modes, the influence of different types of FB managers, their motivations and strategic objectives during international expansion, the level of professionalization and how long the manager has been working at the company. The ability of the family managers to bring about a commitment to internationalization may depend on their capability in gaining the consensus of the family owners (Graves \& Thomas, 2008). 
In our study, we assume that managers behave like stewards when they are members of the family. In this situation, they can undertake more risky international strategies in order to ensure the company continuity and survival. However, using secondary data does not allow us to ensure that their interests are truly aligned with those of the owners. The assumption that FBs have heterogeneous characteristics and behavior is gaining increasing importance in recent years (Cabrera, 2012). Families may be very diverse because they have not only a different culture but also specific values, behavioral patterns and relationships. Therefore, it would be necessary to examine these differences in more depth, insofar as they can explain different international strategic behaviors. Future studies could collect primary data in order to overcome these limitations.

Moreover, our study focuses on a single industry from a particular country, which means that the results cannot be extrapolated to other industries and countries. Future studies could perform a multilevel analysis considering a macro level (country) to prove the effect that the home country has on entry mode choice by FBs (Peng \& Jiang, 2010).

In addition, other variables could be included in future research such as the financial situation of the FB prior to make the decision on going global. Using debt to expand abroad may increase the likelihood of agency conflicts between debtholders and shareholders (Zahra, 2003). Finally, the influence of family involvement on performance is another topic that has received attention in the FB literature (Boyle et al., 2012; García-Castro \& Aguilera, 2014; Kim \& Gao, 2013). Hence, the performance implications of the interplay between family character and institutional factors when choosing entry modes would be another promising line of future research. 


\section{References}

Abdellatif, M., Amann, B. \& Jaussaud, J. (2010). Family versus nonfamily business: A comparison of international strategies. Journal of Family Business Strategy, 1(2), 108116.

Agarwal, S. \& Ramaswami, S. (1992). Choice of foreign market entry mode: Impact of ownership, location, and internalization factors. Journal of International Business Studies, 23(1), 1-27.

Andreu, R., Claver, E. \& Quer, D. (2017a). International geographic diversification of Spanish hotel chains during the crisis period. Cuadernos de Turismo, 40, 45-63.

Andreu, R., Claver, E. \& Quer, D. (2017b). Foreign market entry mode choice of hotel companies: Determining factors. International Journal of Hospitality Management, 62 , 111-119.

Andreu, R., Claver, E., Quer, D. \& Rienda, L. (2018). Family ownership and Spanish hotel chains: An analysis of their expansion through internationalization. Universia Business Review (continued as UCJC Business and Society Review), 59, 40-75.

Arregle, J.L., Duran, P., Hitt, M.A. \& van Essen, M. (2017). Why is family firms' internationalization unique? A meta-analysis. Entrepreneurship Theory and Practice, 41(5), 801-831.

Berbel, J.M. \& Ramírez, J.M. (2011). Does the foreign market entry mode choice affect export performance? The case of the Spanish hotel industry. Journal of Business Economics and Management, 12(2), 301-316.

Berrone, P., Cruz, C. \& Gomez-Mejia, L.R. (2012). Socioemotional wealth in family firms theoretical dimensions, assessment approaches, and agenda for future research. Family Business Review, 25(3), 258-279. 
Boyle, E.H., Pollack, J.M. \& Rutherford, M.W. (2012). Exploring the relation between family involvement and firms' financial performance: A meta-analysis of main and moderator effects. Journal of Business Venturing, 27(1), 1-18.

Brida, J.G., Driha, O., Ramón, A.B. \& Scuderi, F. (2015). Dynamics of internationalisation of the hotel industry: The case of Spain. International Journal of Contemporary Hospitality Management, 27 (5), 1024-1047.

Brida, J.G., Ramón, A.B., Such, M.J. \& Driha, O. (2016). The inverted-U relationship between the degree of internationalization and the performance: The case of Spanish hotel sector. Tourism Management Perspectives, 17, 72-81.

Brouthers, K.D. (2002). Institutional, cultural and transaction cost influences on entry mode choice and performance. Journal of International Business Studies, 33(2), 203-221.

Brouthers, K.D. \& Brouthers, L.E. (2003). Why service and manufacturing entry mode choices differ: The influence of transaction cost factors, risk and trust. Journal of Management Studies, 40(5), 1179-1204.

Brown, J. \& Dev, C. (2000). Improving productivity in a service business: Evidence from de hotel industry. Journal of Service Research, 2(4), 339-354.

Brown, J.R., Dev, C.S. \& Zhou, Z. (2003). Broadening the foreign market entry mode decision: Separating ownership and control. Journal of International Business Studies, 34(5), 473-488.

Cabrera, M.K. (2012). Family influence on family firm: Socioemotional goals, stewardship and familiness. Revista de Empresa Familiar, 2(2), 93-96.

Chen, H. \& Hu, M.Y. (2002). An analysis of determinants of entry mode and its impact on performance. International Business Review, 11(2), 193-210.

Chen, J.J. \& Dimou, I. (2005). Expansion strategy of international hotel firms. Journal of Business Research, 58(12), 1730-1740. 
Chen, R., Cui, L., Li, S. \& Rolfe, R. (2017). Acquisition or greenfield entry into Africa? Responding to institutional dynamics in an emerging continent. Global Strategy Journal, 7(2), 212-230.

Claver, E., Rienda, L. \& Quer, D. (2007). The internationalisation process in family firms: choice of market entry strategies. Journal of General Management, 33(1), 1-16.

Claver, E., Rienda, L. \& Quer, D. (2008). Factores familiares y compromiso internacional: Evidencia empírica en las empresas españolas. Cuadernos de Economía y Dirección de la Empresa, 35, 7-26.

Contractor, F.J. \& Kundu, S.K. (1998). Modal choice in a world of alliances: Analyzing organizational forms in the international hotel sector. Journal of International Business Studies, 29(2), 325-358.

Davis, J.H., Schoorman, F.D. \& Donaldson, L. (1997). Toward a stewardship theory of management. Academy of Management Review, 22(1), 20-47.

Dimou, I., Chen, J. \& Archer, S. (2003). The choice between management contracts and franchise agreements in the corporate development of international hotel firms. Journal of Marketing Channels, 10(3-4), 33-52.

Donaldson, L. \& Davis, J. (1991). Stewardship Theory or Agency Theory: CEO governance and shareholder returns. Australian Journal of Management, 16(1), 49-64.

Driha, O. \& Ramón, A. (2011). Determinantes de la elección del modo de entrada de las hoteleras españolas en mercados foráneos. Papeles de Economía Española, 128, 296315.

Eddleston, K.A. \& Kellermanns, F.W. (2007). Destructive and productive family relationships: A stewardship theory perspective. Journal of Business Venturing, 22(4), $545-565$. 
Fernández, Z. \& Nieto, M.J. (2005). Internationalization strategy of small and medium-sized family businesses: Some influential factors. Family Business Review, 18(1), 77-89.

García-Castro, R. \& Aguilera, R.V. (2014). Family involvement in business and financial performance: A set-theoretic cross-national inquiry. Journal of Family Business Strategy, 5, 85-96.

García de Soto, E. \& Vargas, A. (2015). Choice of entry mode, strategic flexibility and performance of international strategy in hotel chains: An approach based on real options. European Journal of Tourism Research, 9, 92-114.

Gatignon, H.A. \& Anderson, E. (1988). The multinational corporation's degree of control over foreign subsidiaries: An empirical test of a transaction cost explanation. Journal of Law, Economics and Organization, 4(2), 305-336.

Gaur, A.S. \& Lu, J.W. (2007). Ownership strategies and survival of foreign subsidiaries: Impacts of institutional distance and experience. Journal of Management, 33(1), 84110.

Gómez-Mejía, L.R., Haynes, K.T., Nunez-Nickel, M., Jacobson, K.J.L. \& Moyano-Fuentes, J. (2007). Socioemotional wealth and business risks in family-controlled firms: Evidence from Spanish olive oil mills. Administrative Science Quarterly, 52(1), 106-137.

Gómez-Mejía, L.R., Makri, M. \& Larraza, M. (2010). Diversification decisions in familycontrolled firms. Journal of Management Studies, 47(2), 223-252.

Graves, C., \& Thomas, J. (2008). Determinants of the internationalization pathways of family firms: An examination of family influence. Family Business Review, 21(2), 151-167.

Hofstede, G. (1980). Culture's Consequences. International Differences in Work-Related Values. Newbury Park, CA: Sage Publications. 
Hofstede, G., Hofstede, G. J. \& Minkov, M. (2010). Cultures and Organizations. Software of the Mind. Intercultural Cooperation and its Importance for Survival, $3^{\text {rd }}$ edition. New York: McGraw-Hill.

Ivanova, M. \& Ivanov, S. (2014). Hotel chain's entry mode in Bulgaria. Anatolia: An International Journal of Tourism and Hospitality Research, 25(1), 131-135.

James, H.S. (1999). Owners as manager, extended horizons and the family firm. International Journal of the Economics of Business, 6(1), 41-55.

Kaufmann, D., Kraay, D. \& Mastruzzi, M. (2009). Governance matters VIII: Aggregate and individual governance indicators 1996-2008. The World Bank. Policy Research Working Paper 4978.

Kim, Y. \& Gao, F.Y. (2013). Does family involvement increase business performance? Family-longevity goals' moderating role in Chinese family firms. Journal of Business Research, 66, 265-274.

Kogut, B. \& Singh, H. (1988). The effect of national culture on the choice of entry mode. Journal of International Business Studies, 19(3), 411-432.

Kontinen, T. \& Ojala, A. (2010). The internationalization of family businesses: A review of extant research. Journal of Family Business Strategy, 1(2), 97-107.

Kraus, S., Mensching, H., Calabrò, A., Cheng, C.F. \& Filser, M. (2016). Family firm internationalization: A configurational approach. Journal of Business Research, 69(11), $5473-5478$.

Kruesi, M., Kim, P.B. \& Hemmington, N. (2017). Evaluating foreign market entry mode theories from a hotel industry perspective. International Journal of Hospitality Management, 62, 88-100. 
Kruesi, M.A., Hemmington, N.R. \& Kim, P.B. (2018). What matters for hotel executives? An examination of major theories in non-equity entry mode research. International Journal of Hospitality Management, 70, 25-36.

Kutner, M.H., Nachtsheim, C.J., Neter, J. \& Li, W. (2005). Applied Linear Statistical Models, $5^{\text {th }}$ edition. New York: McGraw-Hill/Irwin.

Lee, P.M. \& O’Neill, H.M. (2003). Ownership structures and R\&D investments of U.S. and Japanese firms: agency and Stewardship perspectives. Academy of Management Journal, 46(2), 212-225.

León, F., Villar, C. \& Pla, J. (2011). Entry mode choice in the internationalisation of the hotel industry: a holistic approach. The Service Industries Journal, 31(1), 107-122.

Lu, J.W. \& Beamish, P.W. (2004). International diversification and firm performance: The Scurve hypothesis. Academy of Management Journal, 47(4), 598-609.

Malhotra, S. \& Gaur, A.S. (2014). Spatial geography and control in foreign acquisitions, Journal of International Business Studies, 45(2), 191-210.

Martorell, O., Mulet, C. \& Otero, L. (2013). Choice of market entry mode by Balearic hotel chains in the Caribbean and Gulf of Mexico. International Journal of Hospitality Management, 32, 217-227.

Meyer, K.E., van Witteloostuijn, A. \& Beugelsdijk, S. (2017). What's in a p? Reassessing best practices for conducting and reporting hypothesis testing research. Journal of International Business Studies, 48(5), 535-551.

Miller, D., Le Breton-Miller, I. \& Lester, R.H. (2010). Family ownership and acquisition behavior in publicly-traded companies. Strategic Management Journal, 31(2), 201223. 
Miller, D., Le Breton-Miller, I. \& Scholnick, B. (2008). Stewardship vs. stagnation: An empirical comparison of small family and non-family businesses. Journal of Management Studies, 45(1), 51-78.

Miller, D., Steier, L. \& LeBreton-Miller, I. (2003). Lost in time: intergenerational succession, change, and failure in family business. Journal of Business Venturing, 18, 513-531.

Nguyen, Q., Kim, T. \& Papanastassiou, M. (2018). Policy uncertainty, derivatives use, and firm-level FDI. Journal of International Business Studies, 49(1), 96-126.

Niñerola, A., Campa, F., Hernández, A.B. \& Sánchez, M.V. (2016). The experience of Meliá Hotels International in China: A case of internationalisation of a Spanish hotel group. European Journal of Tourism Research, 12, 191-196.

North, D.C. (1990). Institutions, Institutional Change and Economic Performance. Cambridge: Cambridge University Press.

Pak, Y.S. \& Park, Y.R. (2004). Global ownership strategy of Japanese multinational enterprises: A test of Internalization Theory. Management International Review, 44(1), $3-21$.

Peng, M.W. (2000). Business Strategies in Transition Economies. Thousand Oaks, CA: Sage.

Peng, M.W. \& Jiang, Y. (2010). Institutions behind family ownership and control in large firms. Journal of Management Studies, 47(2), 253-273.

Pinto, C., Ferreira, M., Falaster, C., Fleury, M.T. \& Fleury, A. (2017). Ownership in crossborder acquisitions and the role of government support. Journal of World Business, 52(4), 533-545.

Pla, J. \& Ghauri, P.N. (2012). Internationalization of service industry firms: Understanding distinctive characteristics. The Service Industries Journal, 32(7), 1007-1010.

Pla, J., León, F. \& Villar, C. (2011). The internationalization of soft-services: Entry modes and main determinants in the Spanish hotel industry. Service Business, 5(2), 139-154. 
Pla, J., Sánchez, E. \& Madhok, A. (2010). Investment and control decisions in foreign markets: Evidence from service industries. British Journal of Management, 21(3), 736-753.

Pukall, T.J. \& Calabrò, A. (2014). The internationalization of family firms: A critical review and integrative model. Family Business Review, 27(2), 103-125.

Ramón, A. (2002). Determining factors in entry choice for international expansion. The case of the Spanish hotel industry. Tourism Management, 23(6), 597-607.

Schwens, C., Eiche, J. \& Kabst, R. (2011). The moderating impact of informal institutional distance and formal institutional risk on SME entry mode choice. Journal of Management Studies, 48(2), 330-351.

Sciascia, S., Mazzola, P., Astrachan, J.H. \& Pieper, T.M. (2012). The role of family ownership in international entrepreneurship: Exploring nonlinear effects. Small Business Economics, 38(1), 15-31.

Slangen, A.H.L. (2011). A communication-based theory of the choice between greenfield and acquisition entry. Journal of Management Studies, 48(8), 1699-1726.

Slangen, A.H.L. \& van Tulder, R.J.M. (2009). Cultural distance, political risk, or governance quality? Towards a more accurate conceptualization and measurement of external uncertainty in foreign entry mode research. International Business Review, 18(3), 276291.

Tallman, S. \& Li, J. (1996). Effects of international diversity and product diversity on performance of multinational firms. Academy of Management Journal, 39(1), 179-196.

UNWTO (2017): Tourism highlights. Available at: https://www.eunwto.org/doi/pdf/10.18111/9789284419029 
Vargas, A. (2001). La Teoría de la Agencia versus la Teoría del Servidor: una aplicación a las sociedades cooperativas agrarias de la provincia de Huelva. Best papers proceedings $X$ International Conference of AEDEM. Reggio Calabria (Italy), 1067-1076.

Villar, C., Pla, J. \& León, F. (2012). Service characteristics as moderators of the entry mode choice: empirical evidence in the hotel industry. The Service Industries Journal, 32(7), $1137-1148$.

Wright, M., Chrisman, J.J., Chua, J.H. \& Steier, L.P. (2014). Family enterprise and context. Entrepreneurship Theory and Practice, 38(6), 1247-1260

Zahra, S.A. (2003). International expansion of U.S. manufacturing family businesses: The effect of ownership and involvement. Journal of Business Venturing, 18(4), 495-512.

Zahra, S. A. (2005). Entrepreneurial risk taking in family firms. Family Business Review, 18, $23-40$.

Zhao, H., Luo, Y. \& Suh, T. (2004). Transaction cost determinants and ownership-based entry mode choice: A meta-analytical review. Journal of International Business Studies, $35(6), 524-544$. 
Table 1: Sample description

\begin{tabular}{clc}
\hline & & Number of entries abroad \\
\hline & Franchise & 256 \\
Entry mode & Management contract & 51 \\
& Lease contract & 266 \\
& Ownership (FDI) & 408 \\
\hline \multirow{5}{*}{ Family involvement } & NFBs & 385 \\
& Firms with low family involvement & 4 \\
& Family-managed firms & 5 \\
& Family-owned firms & 466 \\
& Family-owned and managed firms & 121 \\
\hline \multirow{5}{*}{ Family generation } & First generation & 78 \\
& Second generation & 294 \\
& Third generation & 68 \\
& Fourth generation & 156 \\
\hline \multirow{2}{*}{ Family CEO } & Family CEO & 584 \\
& Non-family CEO & 397 \\
\hline \multirow{5}{*}{ Top 10 destinations } & Mexico & 121 \\
& Germany & 114 \\
& Dominican Republic & 88 \\
& Italy & 80 \\
& Cuba & 72 \\
& Portugal & 60 \\
& Netherlands & 43 \\
& Colombia & 37 \\
& Argentina & 30 \\
& & 25 \\
\hline
\end{tabular}


Table 2: Variable description

\begin{tabular}{|c|c|c|}
\hline Variable & Measurement and coding & Information source \\
\hline Entry mode & $\begin{array}{l}\text { (1) Franchise; (2) Management } \\
\text { contract; (3) Lease contract; (4) } \\
\text { Ownership (partial and total) }\end{array}$ & $\begin{array}{l}\text { Alimarket Hotel and } \\
\text { Catering Yearbook }\end{array}$ \\
\hline Family involvement & $\begin{array}{l}\text { (1) NFBs; (2) Firms with low } \\
\text { family involvement; (3) Family- } \\
\text { managed firms; (4) Family-owned } \\
\text { firms; (5) Family-owned and } \\
\text { family-managed firms }\end{array}$ & $\begin{array}{l}\text { Alimarket Hotel and } \\
\text { Catering Yearbook }\end{array}$ \\
\hline Formal institutional distance & Kogut and Singh (1988) index & $\begin{array}{c}\text { Six dimensions of } \\
\text { Worldwide } \\
\text { Governance Indicators } \\
\text { (WGI) }\end{array}$ \\
\hline Cultural distance & Kogut and Singh (1988) index & $\begin{array}{l}\text { Extended Hofstede's } \\
\text { model of cultural } \\
\text { differences with six } \\
\text { dimensions }\end{array}$ \\
\hline International experience & $\begin{array}{l}\text { Number of years since the firm's } \\
\text { internationalization process began } \\
\text { Ratio of rooms abroad to total } \\
\text { rooms of each hotel chain }\end{array}$ & $\begin{array}{l}\text { Alimarket Hotel and } \\
\text { Catering Yearbook }\end{array}$ \\
\hline Firm size & $\begin{array}{l}\text { Average income of each hotel } \\
\text { chain in the last three years }\end{array}$ & $\begin{array}{l}\text { Alimarket Hotel and } \\
\text { Catering Yearbook }\end{array}$ \\
\hline Family generation & $\begin{array}{l}\text { Current generation of the family } \\
\text { running the firm }\end{array}$ & $\begin{array}{l}\text { Firm's corporate } \\
\text { website }\end{array}$ \\
\hline Family CEO & $\begin{array}{l}\text { (1) The CEO is a family member; } \\
\text { (0) Otherwise }\end{array}$ & $\begin{array}{l}\text { Alimarket Hotel and } \\
\text { Catering Yearbook }\end{array}$ \\
\hline Market attractiveness & Tourism income of each country & UNWTO (2017) \\
\hline
\end{tabular}


Table 3: Descriptive statistics and correlation matrix

\begin{tabular}{|c|c|c|c|c|c|c|c|c|c|c|c|c|}
\hline Variable & Mean & SD & VIF & 1 & 2 & 3 & 4 & 5 & 6 & 7 & 8 & 9 \\
\hline 1. Entry mode & 2.84 & 1.22 & N.A. & 1 & & & & & & & & \\
\hline 2. Family involvement & 2.93 & 1.59 & 1.65 & 0.085 & 1 & & & & & & & \\
\hline $\begin{array}{l}\text { 3. Formal institutional } \\
\text { distance }\end{array}$ & 1.06 & 1.01 & 2.70 & -0.159 & 0.113 & 1 & & & & & & \\
\hline 4. Cultural distance & 7.13 & 3.84 & 1.79 & 0.113 & 0.106 & 0.477 & 1 & & & & & \\
\hline $\begin{array}{l}\text { 5. International experience } \\
\text { (years) }\end{array}$ & 20.83 & 9.03 & 4.43 & -0.020 & 0.189 & 0.002 & 0.169 & 1 & & & & \\
\hline $\begin{array}{l}\text { 6. International experience } \\
\text { (rooms) }\end{array}$ & 58.62 & 18.86 & 2.38 & 0.193 & -0.305 & -0.023 & 0.132 & 0.212 & 1 & & & \\
\hline 7. Firm size & 2.82 & 0.69 & 3.29 & -0.201 & -0.002 & -0.020 & -0.017 & 0.687 & 0.277 & 1 & & \\
\hline 8. Family generation & 2.51 & 1.02 & 2.65 & 0.070 & -0.488 & 0.006 & -0.43 & 0.591 & 0.684 & 0.168 & 1 & \\
\hline 9. Family CEO & 0.96 & 0.19 & 1.16 & 0.036 & 0.085 & 0.014 & 0.086 & 0.265 & 0.101 & 0.290 & 0.066 & 1 \\
\hline 10. Market attractiveness & 4.09 & 0.59 & 1.95 & 0.263 & -0.123 & -0.592 & -0.43 & 0.073 & 0.125 & 0.017 & 0.051 & 0.082 \\
\hline
\end{tabular}

Correlations over $/ 0.073$ / are significant with $p<0.05$

Correlations over $/ 0.085 /$ are significant with $p<0.01$

Table 4: Ordinal logistic regression results of entry mode choice

\begin{tabular}{|c|c|c|c|c|c|}
\hline Explanatory variables & Model 1 & Model 2 & Model 3 & Model 4 & Model 5 \\
\hline Formal institutional distance & & $-0.564 * * *$ & $-7.472 * * *$ & $-0.526 * * *$ & $-7.766 * * *$ \\
\hline Cultural distance & & $0.094 * * *$ & 0.035 & $-1.037 * * *$ & 0.220 \\
\hline \multicolumn{6}{|l|}{ Moderating variable } \\
\hline Family involvement & & $0.672 * *$ & $-2.127 * * *$ & $-1.812 * * *$ & $-1.843^{* * *}$ \\
\hline \multicolumn{6}{|l|}{ Interactions } \\
\hline $\begin{array}{l}\text { Formal institutional distance } \mathrm{X} \\
\text { Family involvement }\end{array}$ & & & $1.728 * * *$ & & $1.796 * * *$ \\
\hline $\begin{array}{l}\text { Cultural distance X Family } \\
\text { involvement }\end{array}$ & & & & $0.269 * * *$ & -0.044 \\
\hline \multicolumn{6}{|l|}{ Control variables } \\
\hline International experience (years) & $0.234 * * *$ & $0.175 * * *$ & $0.256^{* * *}$ & $0.224 * * *$ & $0.255 * * *$ \\
\hline International experience (rooms) & $0.247 * * *$ & $0.175^{* * *}$ & $0.310^{* * *}$ & $0.243 * * *$ & $0.304 * * *$ \\
\hline Firm size & $-12.273 * * *$ & $-7.700 * * *$ & $-15.212 * * *$ & $-11.867 * * *$ & $-14.919 * * *$ \\
\hline Family generation & $-2.901 * * *$ & $-1.928 * * *$ & $-3.740 * * *$ & $-2.853 * * *$ & $-3.668 * * *$ \\
\hline Family CEO & $9.813 * * *$ & $5.367 * * *$ & $11.323 * * *$ & $8.690 * * *$ & $11.140 * * *$ \\
\hline Market attractiveness & $1.002 * * *$ & $0.739 * * *$ & $0.809 * * *$ & $0.701 * * *$ & $0.820 * * *$ \\
\hline $\begin{array}{c}\text { Chi-square } \\
\mathrm{N}=981\end{array}$ & $252.221 * * *$ & $264.426 * * *$ & $296.578 * * *$ & $275.615 * * *$ & $296.881 * * *$ \\
\hline
\end{tabular}


Table 5: Robustness tests

\begin{tabular}{|c|c|c|c|c|c|c|c|c|}
\hline Model 2a & $\begin{array}{l}\text { Model 3a } \\
\end{array}$ & Model 4a & Model 2b & Model 3b & Model 4b & Model 2c & Model 3c & Model 4c \\
\hline Explanatory variables & Explanatory variables & Explanatory variables & Explanatory variables & Explanatory variables & Explanatory variables & Explanatory variables & Explanatory variables & Explanatory variables \\
\hline $\begin{array}{l}\text { Formal inst. distance } \\
\left(-0.679^{* * *}\right)\end{array}$ & $\begin{array}{l}\text { Formal inst. distance } \\
\left(-0.930^{* * *}\right)\end{array}$ & $\begin{array}{l}\text { Formal inst. distance } \\
(-0.691 * * *)\end{array}$ & $\begin{array}{l}\text { Formal inst. distance } \\
(-0.666 * *)\end{array}$ & $\begin{array}{l}\text { Formal inst. distance } \\
\left(-4.140^{* * *}\right)\end{array}$ & $\begin{array}{l}\text { Formal inst. distance } \\
\left(-0.526^{* * *}\right)\end{array}$ & $\begin{array}{l}\text { Formal inst. distance } \\
\left(-0.715^{* * *}\right)\end{array}$ & $\begin{array}{l}\text { Formal inst. distance } \\
\left(-8.055^{* * *}\right)\end{array}$ & $\begin{array}{l}\text { Formal inst. distance } \\
\left(-0.717^{* * *}\right)\end{array}$ \\
\hline $\begin{array}{l}\text { Cultural distance } \\
\left(0.115^{* * *}\right)\end{array}$ & $\begin{array}{l}\text { Cultural distance } \\
\left(0.103^{* * *}\right)\end{array}$ & $\begin{array}{l}\text { Cultural distance } \\
\left(0.087^{* *}\right)\end{array}$ & $\begin{array}{l}\text { Cultural distance } \\
\left(0.121^{* * *)}\right.\end{array}$ & $\begin{array}{l}\text { Cultural distance } \\
(0.124 * * *)\end{array}$ & $\begin{array}{l}\text { Cultural distance } \\
(-1.037 * * *)\end{array}$ & $\begin{array}{l}\text { Cultural distance } \\
\left(0.070^{* *}\right)\end{array}$ & $\begin{array}{l}\text { Cultural distance } \\
\left(0.081^{* *}\right)\end{array}$ & $\begin{array}{l}\text { Cultural distance } \\
\left(-0.553^{* *}\right)\end{array}$ \\
\hline Moderating variable & Moderating variable & Moderating variable & Moderating variable & Moderating variable & Moderating variable & Moderating variable & Moderating variable & Moderating variable \\
\hline \multirow[t]{4}{*}{$\begin{array}{l}\text { Family management } \\
\left(0.046^{* * *}\right)\end{array}$} & $\begin{array}{l}\text { Family management } \\
\left(0.044^{* * *)}\right.\end{array}$ & $\begin{array}{l}\text { Family management } \\
\left(0.039^{* * *}\right)\end{array}$ & $\begin{array}{l}\text { Family involvement } \\
(0.772 * *)\end{array}$ & $\begin{array}{l}\text { Family involvement } \\
(-0.281)\end{array}$ & $\begin{array}{l}\text { Family involvement } \\
\left(-1.812^{* * *}\right)\end{array}$ & $\begin{array}{l}\text { Family involvement } \\
\left(0.554^{*}\right)\end{array}$ & $\begin{array}{l}\text { Family involvement } \\
(-1.547 * * *)\end{array}$ & $\begin{array}{l}\text { Family involvement } \\
(-0.921)\end{array}$ \\
\hline & Interactions & Interactions & & Interactions & Interactions & & Interactions & Interactions \\
\hline & $\begin{array}{l}\text { Formal inst. distance } X \\
\text { Family management } \\
\left(0.015^{* * *}\right)\end{array}$ & & & $\begin{array}{l}\text { Formal inst. distance } \mathrm{X} \\
\text { Family involvement } \\
\left(0.848^{* * *}\right)\end{array}$ & & & $\begin{array}{l}\text { Formal inst. distance } \\
\text { X Family involvement } \\
\left(1.768^{* * *}\right)\end{array}$ & \\
\hline & & $\begin{array}{l}\text { Cultural distance } X \\
\text { Family management } \\
(0.001)\end{array}$ & & & $\begin{array}{l}\text { Cultural distance X } \\
\text { Family involvement } \\
\left(0.269^{* * *}\right)\end{array}$ & & & $\begin{array}{l}\text { Cultural distance X } \\
\text { Family involvement } \\
\left(0.152^{* *}\right)\end{array}$ \\
\hline Control variables & Control variables & Control variables & Control variables & Control variables & Control variables & Control variables & Control variables & Control variables \\
\hline $\begin{array}{l}\text { International } \\
\text { experience (years) } \\
\left(0.327^{* * *}\right)\end{array}$ & $\begin{array}{l}\text { International } \\
\text { experience (years) } \\
\left(0.362^{* * *}\right)\end{array}$ & $\begin{array}{l}\text { International } \\
\text { experience (years) } \\
\left(0.337^{* * *}\right)\end{array}$ & $\begin{array}{l}\text { International } \\
\text { experience (years) } \\
\left(0.111^{* * *}\right)\end{array}$ & $\begin{array}{l}\text { International } \\
\text { experience (years) } \\
(0.124 * * *)\end{array}$ & $\begin{array}{l}\text { International } \\
\text { experience (years) } \\
(0.224 * * *)\end{array}$ & $\begin{array}{l}\text { International } \\
\text { experience (years) } \\
\left(0.666^{* * *}\right)\end{array}$ & $\begin{array}{l}\text { International } \\
\text { experience (years) } \\
\left(0.701^{* * *}\right)\end{array}$ & $\begin{array}{l}\text { International } \\
\text { experience (years) } \\
(0.662 * * *)\end{array}$ \\
\hline $\begin{array}{l}\text { International } \\
\text { experience (rooms) } \\
(0.134 * * *)\end{array}$ & $\begin{array}{l}\text { International } \\
\text { experience (rooms) } \\
\left(0.139^{* * *}\right)\end{array}$ & $\begin{array}{l}\text { International } \\
\text { experience (rooms) } \\
\left(0.130^{* * *}\right)\end{array}$ & $\begin{array}{l}\text { International } \\
\text { experience (rooms) } \\
\left(0.047^{* * *}\right)\end{array}$ & $\begin{array}{l}\text { International } \\
\text { experience (rooms) } \\
\left(0.085^{* * *}\right)\end{array}$ & $\begin{array}{l}\text { International } \\
\text { experience (rooms) } \\
\left(0.243^{* * *}\right)\end{array}$ & $\begin{array}{l}\text { International } \\
\text { experience (rooms) } \\
\left(0.156^{* * *}\right)\end{array}$ & $\begin{array}{l}\text { International } \\
\text { experience (rooms) } \\
\left(0.188^{* * *}\right)\end{array}$ & $\begin{array}{l}\text { International } \\
\text { experience (rooms) } \\
\left(0.176^{* * * *}\right)\end{array}$ \\
\hline $\begin{array}{l}\text { Family generation } \\
\left(-1.444^{* *}\right)\end{array}$ & $\begin{array}{l}\text { Family generation } \\
\left(-1.480^{* *}\right)\end{array}$ & $\begin{array}{l}\text { Family generation } \\
\left(-1.421^{* * *)}\right.\end{array}$ & $\begin{array}{l}\text { Family generation } \\
(-0.519 * * *)\end{array}$ & $\begin{array}{l}\text { Family generation } \\
\left(-0.441^{* * *}\right)\end{array}$ & $\begin{array}{l}\text { Family generation } \\
\left(-2.853^{* * *}\right)\end{array}$ & $\begin{array}{l}\text { Family generation } \\
\left(-3.811^{* * *}\right)\end{array}$ & $\begin{array}{l}\text { Family generation } \\
(-4.184 * * *)\end{array}$ & $\begin{array}{l}\text { Family generation } \\
\left(-4.061^{* * *}\right)\end{array}$ \\
\hline $\begin{array}{l}\text { Family CEO } \\
\left(2.309^{* *}\right)\end{array}$ & $\begin{array}{l}\text { Family CEO } \\
(1.195)\end{array}$ & $\begin{array}{l}\text { Family CEO } \\
\left(1.953^{* *}\right)\end{array}$ & $\begin{array}{l}\text { Family CEO } \\
(1.641 * *)\end{array}$ & $\begin{array}{l}\text { Family CEO } \\
\left(1.376^{* *}\right)\end{array}$ & $\begin{array}{l}\text { Family CEO } \\
\left(8.690^{* * *}\right)\end{array}$ & $\begin{array}{l}\text { Family CEO } \\
(5.007 * * *)\end{array}$ & $\begin{array}{l}\text { Family CEO } \\
\left(6.015^{* * *}\right)\end{array}$ & $\begin{array}{l}\text { Family CEO } \\
\left(5.451^{* * *}\right)\end{array}$ \\
\hline \multirow[t]{5}{*}{$\begin{array}{l}\text { Market attractiveness } \\
\left(0.486^{* *}\right)\end{array}$} & $\begin{array}{l}\text { Market attractiveness } \\
\left(0.463^{* *}\right)\end{array}$ & $\begin{array}{l}\text { Market attractiveness } \\
\left(0.494^{* * *}\right)\end{array}$ & $\begin{array}{l}\text { Market attractiveness } \\
\left(0.591^{* * *}\right)\end{array}$ & $\begin{array}{l}\text { Market attractiveness } \\
\left(0.627^{* *}\right)\end{array}$ & $\begin{array}{l}\text { Market attractiveness } \\
\left(0.701^{* * *}\right)\end{array}$ & $\begin{array}{l}\text { Market attractiveness } \\
\left(1.062^{* * *}\right)\end{array}$ & $\begin{array}{l}\text { Market attractiveness } \\
\left(1.308^{* * *}\right)\end{array}$ & $\begin{array}{l}\text { Market attractiveness } \\
\left(1.131^{* *}\right)\end{array}$ \\
\hline & & & & & & $\begin{array}{l}\text { Number of stars } \\
(0.036)\end{array}$ & $\begin{array}{l}\text { Number of stars } \\
(0.080)\end{array}$ & $\begin{array}{l}\text { Number of stars } \\
(0.061)\end{array}$ \\
\hline & & & & & & $\begin{array}{l}\text { Number of countries } \\
\left(-0.452^{* * *}\right)\end{array}$ & $\begin{array}{l}\text { Number of countries } \\
\left(-0.455^{* * *}\right)\end{array}$ & $\begin{array}{l}\text { Number of countries } \\
\left(-0.450^{* * *}\right)\end{array}$ \\
\hline & & & & & & $\begin{array}{l}\text { Firm size } \\
\text { (employees) } \\
\left(-13.779^{* * *}\right)\end{array}$ & $\begin{array}{l}\text { Firm size } \\
\text { (employees) } \\
(-17.925 * * *)\end{array}$ & $\begin{array}{l}\text { Firm size (employees) } \\
\left(-14.352^{* * *}\right)\end{array}$ \\
\hline & & & & & & $\begin{array}{l}\text { Political risk } \\
(0.098)\end{array}$ & $\begin{array}{l}\text { Political risk } \\
\left(0.197^{*}\right)\end{array}$ & $\begin{array}{l}\text { Political risk } \\
(0.110)\end{array}$ \\
\hline $\begin{array}{l}\text { Chi-square } \\
(286.329 * * *)\end{array}$ & $\begin{array}{l}\text { Chi-square } \\
(298.989 * * *)\end{array}$ & $\begin{array}{l}\text { Chi-square } \\
\left(288.896^{* * *}\right)\end{array}$ & $\begin{array}{l}\text { Chi-square } \\
\left(211.198^{* * *}\right)\end{array}$ & $\begin{array}{c}\text { Chi-square } \\
\left(220.923^{* * *}\right)\end{array}$ & $\begin{array}{c}\text { Chi-square } \\
\left(213.396^{* * *}\right)\end{array}$ & $\begin{array}{c}\text { Chi-square } \\
\left(382.815^{* * *}\right)\end{array}$ & $\begin{array}{c}\text { Chi-square } \\
(405.848 * * *)\end{array}$ & $\begin{array}{c}\text { Chi-square } \\
\left(388.101^{* * *}\right)\end{array}$ \\
\hline $\mathrm{N}=981$ & $\mathrm{~N}=981$ & $\mathrm{~N}=981$ & $\mathrm{~N}=596$ & $\mathrm{~N}=596$ & $\mathrm{~N}=596$ & $\mathrm{~N}=981$ & $\mathrm{~N}=981$ & $\mathrm{~N}=981$ \\
\hline
\end{tabular}

